\title{
Badanie UBM w diagnostyce, leczeniu i prowadzeniu pacjentów z jaskrą
}

The ultrabiomicroscopic examination in diagnostics, treatment and management of patients with glaucoma

Grzegorz Jasina', Marta Misiuk-Hojło ${ }^{2}$

'Szpital Specjalistyczny im. Stefana Żeromskiego w Krakowie Kierownik: dr n. med. Małgorzata Woś

${ }^{2}$ Katedra i Klinika Okulistyki, Uniwersytet Medyczny we Wrocławiu Kierownik: prof. dr hab. n. med. Marta Misiuk-Hojto

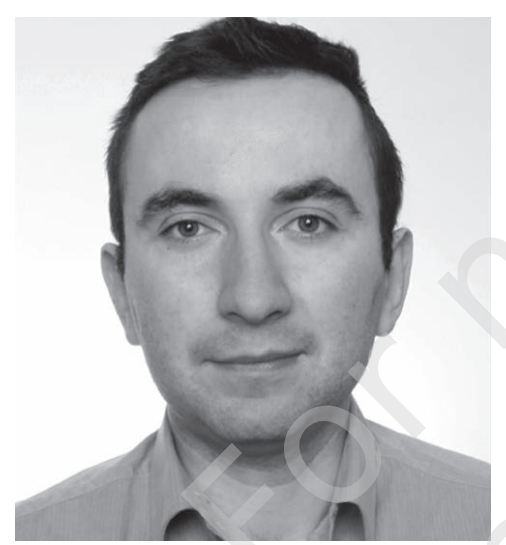

N A JW A ŻN IE JSZE Badanie UBM potrafi bardzo skutecznie wyjaśniać różne patomechanizmy jaskry, a także pomóc w skutecznym leczeniu pacjentów zabiegowych.

\section{H I G H L I G H T S}

The UBM examination can effectively explain various glaucoma pathomechanisms and also help in the effective treatment of patients.

\section{STRESZCZENIE}

Badanie ultrabiomikroskopowe to silne narzędzie diagnostyczne, które może pomóc w prowadzeniu i leczeniu wielu pacjentów. Jest szczególnie pomocne w przypadku jaskry, gdyż nie zawsze patomechanizm powstawania zmian jest znany, a uszkodzenie nerwu wzrokowego często postępuje. Będąc świadomym przyczyny, można skutecznie leczyć pacjenta. Samo badanie UBM nie może jednak zastąpić pełnego badania klinicznego, włącznie z wykonaniem gonioskopii dynamicznej. Jest ono świetnym uzupełnieniem, które może potwierdzić wiele postawionych diagnoz.

Słowa kluczowe: UBM, jaskra, diagnostyka

\section{ABSTRACT}

Ultrabiomicroscopic (UBM) examination is a powerful diagnostic tool that can assist in the management and treatment of many patients. It is especially helpful in the case of glaucoma and damage to the optic nerve. We can successfully treat patients only if we are aware of the disease cause. Although UBM examination cannot replace a complete clinical examination (including dynamic gonioscopy), it is a great supplement that can confirm many diagnoses.

Key words: ultrabiomicroscopic examination, glaucoma, diagnostics 


\section{WSTĘP}

Aby poprawnie zdiagnozować, a następnie leczyć choroby układu wzroku, niezbędne są odpowiednie narzędzia. Dzięki rozwojowi medycyny i nowych technologii lekarze okuliści mają dużo możliwości diagnostycznych i leczniczych. Wśród nich angiografię, USG typu B, OCT (optical coherence tomography), perymetrię, pachymetrię oraz badanie ultrabiomikroskopowe (UBM).

Jedną z najpowszechniejszych chorób oczu jest jaskra. Jest to choroba o tyle niebezpieczna, że w konsekwencji prowadzi do ślepoty. Zgodnie z danymi liczba chorych na jaskrę otwartego kąta w 2020 r. wśród Amerykanów ma wzrosnąć do 3,36 mln ludzi. Badania wskazują, że prawdopodobnie obecnie wśród nich u 84 tys. do 160 tys. osób rozwinęła się obustronna ślepota (dane z 2000 r.).

Właśnie ze względu na skalę oraz skutki jaskry bardzo ważna w jej leczeniu jest odpowiednia diagnostyka. Dobrze by było, gdyby obrazowanie przypadków dotyczyło jak najszerszego obszaru zmian chorobowych. Dlatego też bardzo skuteczną metodą diagnostyczną jest ultrabiomikroskopia.

Badanie UBM jest cennym narzędziem w diagnostyce mechanizmów zamknięcia kąta tęczówkowo-rogówkowego, guzów przedniego odcinka, a także w monitorowaniu efektów chirurgicznych i laserowych zabiegów przeciwjaskrowych. Dokładne badanie pozwoli poznać strukturę kąta przesączania, a także odpowiedzieć na pytania związane z wpływem konfiguracji tęczówki i kształtu soczewki na jego budowę oraz na głębokość komory przedniej [1]. Pierwszą osobą, która podjęła się leczenia chorób oczu przy użyciu metody UBM był Dietlein, który w 2013 r. opisał mechaniczne rozrywanie zrostów w kącie przesączania za pomocą goniopunkcji, a także przy użyciu lasera Er:YAG, bez pomocy mikroskopu operacyjnego. Podczas zabiegu przeprowadzał ultrabiomikroskopię z użyciem głowicy o mocy $50 \mathrm{MHz}$. Posługując się trybem slow motion (w zwolnionym tempie), zaobserwował, że instrumenty były wyraźnie widoczne, natomiast artefakty zaledwie minimalnie [2]. Eksperyment był wykonany na gałkach świńskich, jednak pokazał możliwości, jakie niesie za sobą UBM. Być może w przyszłości podobne zabiegi będziemy wykonywać na naszych pacjentach.

Należy pamiętać, że badanie UBM jest badaniem dodatkowym. Prowadząc pacjenta z jaskrą, należy najpierw wykonać badanie gonioskopowe.

\section{PROWADZENIE PACJENTA}

U pacjenta, który zgłasza się z powodu okresowych bólów oczu i głowy, ma rozpoznaną jaskrę zamkniętego kąta bądź może być zagrożony zamknięciem kąta, warto zastano- wić się nad przeprowadzeniem oceny czynnościowej kąta tęczówkowo-rogówkowego. Zazwyczaj ocenę przeprowadza się, wykonując test zmian w konfiguracji kąta przesączania w warunkach jasnego oświetlenia i w ciemności. Standardowy test sprawdza zmiany ciśnienia wewnątrzgałkowego (CWG) i zmiany stopnia otwarcia kąta przesączania przy zmianie otoczenia z jasnego na ciemne [3]. W celu poprawnego wykonania testu należy zastosować soczewkę kontaktową Goldmanna, a samo badanie powinno odbyć się w lampie szczelinowej. Wiąże się to jednak z pewnymi ograniczeniami, gdyż światło lampy może wpłynąć na jego wyniki.

Problem ten eliminuje badanie UBM. Dzięki niemu możemy przeprowadzić próbę w warunkach braku oświetlenia skierowanego na gałkę oczną, a przy tym realnie ocenić zmiany konfiguracji kąta przesączania w ciemności. Wang porównał tradycyjny test ciemnego pokoju z badaniem UBM. Ocenił wrażliwość standardowego badania na poziomie $31,8 \%$, natomiast badania z użyciem UBM na $68,2 \%$, przy poziomie swoistości $100 \%$ dla obu badań. Oznacza to, że zastosowanie ultrabiomikroskopii przy wykonywaniu tego testu powoduje wzrost wrażliwości badania, redukuje błędy fałszywie negatywne czy pozytywne w badaniach przesiewowych predyspozycji do zamknięcia kąta [4].

Analizując okoliczności, które wpływają na zmiany konfiguracji kąta przesączania, warto wspomnieć o zmianie pozycji ciała. Przeprowadzono badania [5], w których wykazano różnicę przy pozycjach na wznak oraz leżenia na brzuchu. Wyniki pomiarów opisano, posługując się parametrami: AOD 250, AOD500, TIA oraz ACD. Pozycja pacjenta na brzuchu wykazuje mniejsze wartości niż pozycja głową do góry. Przy wykonywaniu oceny zmian konfiguracji kąta można zamiast wykorzystania zmian oświetlenia otoczenia podać pacjentowi mydriatyki i obserwować ich wpływ na zmiany anatomiczne. Warto dodać, że również próba Valsalvy wpływa na konfigurację kąta przesączania. Dada wykazał, że podczas jej trwania wzrasta CWG, spłyca się kąt, kurczy się ciało rzęskowe i wzrasta grubość tęczówki. Udowodniono, że w oczach anatomicznie predysponowanych próba ta może doprowadzić do zamknięcia kąta [6]. Informacja ta jest tak istotna, gdyż próba Valsalvy towarzyszy nam w wielu czynnościach życia codziennego. Badanie UBM jest wysoce skuteczne w obserwacji kąta przesączania, diagnostyce możliwości wystąpienia jego zamknięcia, przewidzeniu mechanizmu, w jakim on nastąpi, a także w obserwacji obwodowych zrostów oraz konfiguracji płaskiej tęczówki. Należy również pamiętać, że w przypadku braku przezierności środków optycznych możemy posiłkować się tym badaniem w celu zobrazowania kąta przesączania. 


\section{UBM W LECZENIU RÓŻNYCH POSTACI JASKRY}

\section{Jaskra pierwotna otwartego kąta}

Użyteczność badania sprowadza się do możliwości wyeliminowania anomalii rozwojowych, które występują w jaskrze pierwotnej wrodzonej. Warto poszukać przyczyn, które mogą prowadzić do jaskry wtórnej otwartego kąta (np. specyficzna wklęsła konfiguracja tęczówki w jaskrze barwnikowej bądź uszkodzenie więzadełek w zespole pseudoeksfoliacji [PEX, pseudoexfoliation syndrome]) [7].

\section{Jaskra wtórna otwartego kąta}

W zespole rozproszonego barwnika, który prowadzi do jaskry barwnikowej, w UBM obserwujemy: wklęsłą konfigurację tęczówki, wyrostki rzęskowe umiejscowione bezpośrednio za tęczówką i dużą długość kontaktu soczewkowo-tęczówkowego (ILCD, iris-lens contact distance). Warto podkreślić, że dzięki UBM potwierdzono wpływ mrugania, wysiłku fizycznego oraz akomodacji na wzrost uwypuklenia się tęczówki ku tyłowi, a w konsekwencji na większe uwalnianie barwnika z tylnej powierzchni tęczówki [1]. Niektórzy badacze opisują wklęsłą konfigurację tęczówki jako odwrócony blok źreniczny. Należy jednak pamiętać, że nie jest to objaw patognomiczny, ponieważ może wystąpić chociażby w przypadkach głębokiej komory przedniej w oczach pseudofakijnych [7].

Obecnie przyjętym postępowaniem, które ma na celu przywrócenie właściwej konfiguracji tęczówki jest wykonanie irydotomii laserowej. Skuteczność tej metody potwierdziło badanie Méndez-Hernández [8], wykazując, że wykonana irydotomia u sześciu osób z rozpoznaną jaskrą barwnikową skutkowała uzyskaniem prawidłowego kształtu tęczówki u pięciu z nich. Inne badania z kolei pokazały, że nie zawsze kontakt tęczówkowo-soczewkowy występuje u wszystkich pacjentów z jaskrą barwnikową. Obserwacje te przeprowadził Pillunat na 28 pacjentach, u których wykonano irydotomię laserową. Z całej próby tylko u 10 osób zabieg wykazał znaczny spadek CWG [9]. Dlatego też trzeba zdać sobie sprawę, że może występować więcej niż jeden mechanizm powstawania jaskry barwnikowej.

W zespole PEX w badaniu UBM możemy uwidocznić materiał pseudoeksfoliacyjny w postaci drobnych, hiperechogennych struktur znajdujących się na śródbłonku, przedniej powierzchni soczewki lub w kącie przesączania, a także brzegu źrenicznym [1] oraz włóknach obwódki rzęskowej [7]. Należy pamiętać, że patofizjologia tego zespołu nie opiera się tylko na zablokowaniu beleczkowania przez materiał pseudoeksfoliacyjny, ale również zablokowaniu na spowodowanym blokiem źrenicznym, który występuje w jaskrze wtórnej zamkniętego kąta. W tym przypadku na skutek osłabienia napięcia obwódki rzęskowej dochodzi do przesunięcia do przodu przepony soczewkowo-tęczówkowej. Warto mieć na uwadze, że dana jednostka chorobowa nie musi występować symetrycznie w obu oczach [7].

Jaskra wtórna otwartego kąta może wystąpić po licznych urazach gałki ocznej bądź w konsekwencji powikłań pooperacyjnych. Urazy gałki ocznej mogą powodować recesję kąta przesączania, czyli rozdarcie przedniej części ciała rzęskowego najczęściej w wyniku tępego urazu. Często z powodu krwi w komorze przedniej obrazowanie beleczkowania za pomocą gonioskopii jest niemożliwe, natomiast w przypadku techniki UBM nie wpływa to na możliwość przeprowadzenia badania. Recesja, która zajmuje powyżej $180^{\circ}$ obwodu komory przedniej, może być przyczyną wzrostu CWG nawet po kilku latach od wystąpienia zdarzenia [7]. Należy jeszcze dodać, że w badaniu UBM możemy również zobrazować cyklodializę, polegającą na tym, że ciało rzęskowe jest odłączone miejscowo od ostrogi twardówki [5], oraz irydodializę, czyli oderwanie tęczówki od nasady ciała rzęskowego.

Wzrost CWG może być spowodowany powikłaniami po operacji zaćmy, m.in. pozostawionymi masami soczewkowymi. W weryfikacji poprawności wykonania zabiegu, a tym samym zapobieżeniu rozwojowi jaskry, stosujemy obrazowanie za pomocą UBM. Daje ono również możliwość sprawdzenia, czy wszczep wewnątrzgałkowy znajduje się we właściwym miejscu albo czy torebka tylna podczas zabiegu nie została naruszona. Niekiedy wyżej opisane elementy wpływają na pooperacyjny wzrost CWG. Warto też pamiętać, iż wtórna jaskra barwnikowa może rozwinąć się po umiejscowieniu soczewki w bruździe rzęskowej. Wtedy tylna powierzchnia tęczówki pociera o przednią powierzchnię wszczepionej soczewki, powodując zespół rozproszenia barwnika [10].

Inną komplikacją pooperacyjną, która może wpłynąć na wystąpienie jaskry wtórnej otwartego kąta, a przy której sprawdza się metoda obrazowania UBM, jest przemieszczenie oleju po operacji witrektomii. Zdarza się, że przedostaje się on do komory przedniej i powoduje wzrost CWG. Dzięki UBM możemy łatwo uwidocznić miejsca wytapetowane olejem jako hiperechogeniczne obszary, które wyraźnie wpływają na pogorszenie kontrastowości struktur leżących poniżej nich [7].

Poza przedstawionymi powyżej przykładami powstawania jaskry wtórnej warto rozważyć wynik obserwacji Wei, który stwierdził, że opasanie gałki ocznej spłyca kąt przesączania. Wysunął on przypuszczenie, że być może obrzęk rogówki i odłączenie ciała rzęskowego są związane z pooperacyjnym zamykaniem kąta po tym zabiegu [11].

W jaskrze fakolitycznej białka soczewki, powstające z jej upłynnienia, powodują blokowanie beleczkowania. Kąt zazwyczaj jest otwarty. W UBM widzimy otwarty kąt, głęboką komorę, torebkę soczewki rozciągniętą przez więzadełka obwódki rzęskowej, a wewnątrz miejsca, w którym powin- 
na być soczewka, zostaje samo jądro, zazwyczaj przesunięte ku dołowi [7].

Innymi chorobami, które mogą powodować wzrost CWG, są choroby pozagałkowe. Należy do nich m.in. zespół Sturge'a-Webera związany z wysokim CWG, przy którym UBM pokazuje poszerzone wewnątrztwardówkowe naczynia i płyn zlokalizowany nad ciałem rzęskowym albo też wzrost oporów w odpływie krwi żylnej z gałki ocznej [5].

\section{Pierwotne zamknięcie kąta}

Do predyspozycji zamykania się kąta przesączania zaliczamy krótką gałkę oczną i stosunkowo dużą soczewkę [7]. W przypadku, gdy stopień rozwarcia kąta przesączania wynosi poniżej $20^{\circ}$, należy rozważyć przeprowadzenie irydotomii laserowej w tym oku. Zabieg ten ma na celu wytworzenie dodatkowej drogi odpływu cieczy wodnistej z komory tylnej, a przez to zablokowanie patomechanizmu bloku źrenicznego. Dzięki badaniu UBM, po zastosowaniu wcześniejszych instrukcji, w łatwy sposób obiektywnie możemy ocenić stopień szerokości kąta przesączania oraz drożność i wielkość wykonanego otworu w tęczówce. Badanie wykonuje się w płaszczyźnie pionowej oraz poziomej, co znacznie ułatwia ocenę pełnościenności otworu.

Istotnym elementem badania jest umiejętność wykonania właściwego otworu w tęczówce podczas zabiegu irydotomii. Fleck w swoich analizach wyliczył właściwy rozmiar laserowej irydotomii (IRT, laser irydotomy), który miałby skutecznie zabezpieczyć oko przed zamknięciem kąta przesączania. Określił jego wielkość na poziomie 150-200 ㅆ [12].

Poza samą wielkością otworu po irydotomii istotne jest również jego umiejscowienie. Użycie UBM pozwala szybko zorientować się w anatomii gałki ocznej. Duża powierzchnia styku tęczówkowo-soczewkowego obliguje wykonanie irydotomii umiejscowionej bardziej obwodowo. Natomiast wyrostki rzęskowe znajdujące się bardzo blisko obwodu tęczówki wymagają irydotomii wykonanej bardziej centralnie [1]. Dlatego też płytka komora występująca po skutecznej irydotomii zdarza się dość często, gdy za tęczówką mamy do czynienia z bliską obecnością wyrostków rzęskowych.

Badania nad morfologią kąta wykazały wpływ irydotomii na jego poszerzenie i zwiększenie głębokości komory przedniej u pacjentów z pierwotnym zamknięciem kąta, przy jednoczesnym braku wpływu w oczach z jaskrą pierwotnie zamkniętego kąta [13].

Oprócz wskazanych powyżej szerokich zalet badania metodą UBM warto wspomnieć o jeszcze jednej jego cesze: podczas użycia ultrabiomikroskopii przy wystąpieniu pełnego bloku źrenicznego dobrze widoczne jest uwypuklenie do przodu tęczówki (iris bombe) i zasłonięcie przez nią kąta przesączania.

\section{Zespół płaskiej tęczówki}

Zespół płaskiej tęczówki (iris plateau) dotyczy nietypowej konfiguracji kąta przesączania, w której usytuowane za bardzo do przodu wyrostki rzęskowe potrafią zawęzić kąt poprzez popychanie obwodowej tęczówki do przodu. Pojawienie się objawu podwójnego garbu (double-hump) powinniśmy traktować jako wystąpienie tegoż zespołu. W badaniu UBM należy odnaleźć pewne cechy zdefiniowane przez Kumara, takie jak:

- Wyrostki rzęskowe zorientowane do przodu wspierają obwodową tęczówkę i sprawiają, że jest równoległą do beleczkowania.

- Nasada tęczówki ma dość znaczące wcięcie.

- Obecność środkowej płaskiej tęczówki.

- Brak bruzdy rzęskowej.

- Kontakt tęczówki z kątem przesączania na wysokości ostrogi twardówki w tym samym kwadrancie [14].

Leczenie zaczyna się od wykonania irydotomii laserowej, która ma na celu wyeliminowanie komponentu bloku źrenicznego. W przypadku stwierdzenia zaćmy należy usunąć soczewkę. W sytuacji kiedy powyższe metody nie przyniosą rezultatów, a pacjentowi nadal zagraża zamknięcie kąta, należy rozważyć przewlekłe stosowanie pilokarpiny bądź też zastosowanie irydoplastyki obwodowej laserem argonowym. U tych pacjentów należy regularnie monitorować kąt przesączania, aby ocenić, czy nie zagraża im zamknięcie kąta.

Garudadri przedstawił badania opisujące wpływ irydotomii na szerokość kąta u pacjentów z zespołem płaskiej tęczówki i jaskrą zamkniętego kąta. Stwierdził, że u 60\% pacjentów występuje kąt wąski (angle opening distance $\leq 130$ mikronów), natomiast u pozostałych $40 \%$ występuje kąt otwarty (angle opening distance > 130 mikronów) [15].

W piśmiennictwie można spotkać się z określeniem jaskra pierwotna zamkniętego kąta $w$ mechanizmie o konfiguracji typu iris plateau. To sytuacja, w której jednocześnie występuje blok źreniczny oraz zespół płaskiej tęczówki. Uważa się, że równoczesne współistnienie tych dwóch patofizjologii odpowiada za większość przyczyn zamknięcia kąta w jaskrze pierwotnej zamkniętego kąta u rasy żółtej [7].

\section{Wtórne zamknięcie kąta z blokiem źrenicznym}

Jaskra fakomorficzna może być z łatwością uwidoczniona $\mathrm{w}$ badaniu UBM. Widzimy wówczas płytką komorę oraz przemieszczenie przepony tęczówkowo-rzęskowej do przodu. Oba te elementy sprzyjają powstaniu bloku źrenicznego i zamknięciu kąta [7]. A im krótsza gałka, tym mniejsza soczewka może je spowodować.

Zdarza się, że podwichnięcie obwódki rzęskowej jest przyczyną drżenia soczewki. W badaniu da się zauważyć przerwane włókna rzęskowe. 
Podczas próby ze zmianą oświetlenia występowanie zrostów tylnych pozwala zaobserwować zmniejszoną ruchomość, a nawet całkowitą recesję ruchową źrenicy. Widoczne są także miejsca styku tęczówki z soczewką, czy to prawdziwą, czy sztuczną, wyglądające jak pogrubione pasma łącznotkankowe [7].

\section{Wtórne zamknięcie kąta bez bloku źrenicznego}

Zdarzają się przypadki prowadzące do zamknięcia kąta przesączania bez patomechanizmu w postaci bloku źrenicznego. Dotyczy to obkurczania się nieprawidłowych struktur (o charakterze tkankowo-naczyniowym lub pozapalnym) znajdujących się na przedniej powierzchni tęczówki i na śródbłonku rogówki, co prowadzi do powstania zrostów przednich, a w konsekwencji do zamknięcia kąta przesączania. Mowa tu m.in. o:

- dystrofii polimorficznej tylnej

- zespole tęczówkowo-rogówkowym

- jaskrze neowaskularnej

- jaskrze zapalnej [7].

Badanie UBM umożliwia zobrazowanie zrostów przednich, występujących w ww. schorzeniach, a także wiele innych cech specyficznych dla danej jednostki chorobowej.

Jaskra złośliwa (zespół skierowania cieczy wodnistej ku tyłowi, blok rzęskowy) to rzadka, potencjalnie agresywna postać jaskry pojawiająca się w konsekwencji zabiegów chirurgicznych, szczególnie wśród pacjentów z występującym zamknięciem kąta lub zrostami przednimi. Przyczyną zamknięcia kąta jest przesunięcie przepony soczewkowo-tęczówkowej do przodu z powodu wzrostu ciśnienia w komorze ciała szklistego [7]. Zdarza się, że powstaje też po irydotomii bądź kapsulotomii laserowej [1]. W badaniu UBM możemy zaobserwować płytką bądź zniesioną komorę przednią z przemieszczeniem do przodu soczewki, wszczepu lub też przedniej powierzchni ciała szklistego w przypadku oczu afakijnych. Rozpoznanie to wymaga odpowiedniej wiedzy, a także przeprowadzenia diagnostyki różnicowej. Niekiedy do ustalenia rozpoznania niezbędna jest interwencja chirurgiczna.

Istnieje wiele przyczyn, które sprawiają, że przepona tęczówkowo-soczewkowa zostanie wypchnięta do przodu, a kąt przesączania zamknięty (w wyniku zwiększenia ciśnienia w komorze ciała szklistego). Należą do nich m.in.: obecność oleju sylikonowego bądź gazu w komorze ciała szklistego, wysiękowe odłączenie błony naczyniówkowej i ciała rzęskowego, cysty tęczówkowo-rzęskowe czy zmiany nowotworowe [7].

U 10\% pacjentów, u których mnogie cysty obejmują więcej niż $180^{\circ}$ obwodu tęczówki, może wystąpić jaskra zamkniętego kąta [16] (ryc. 1).

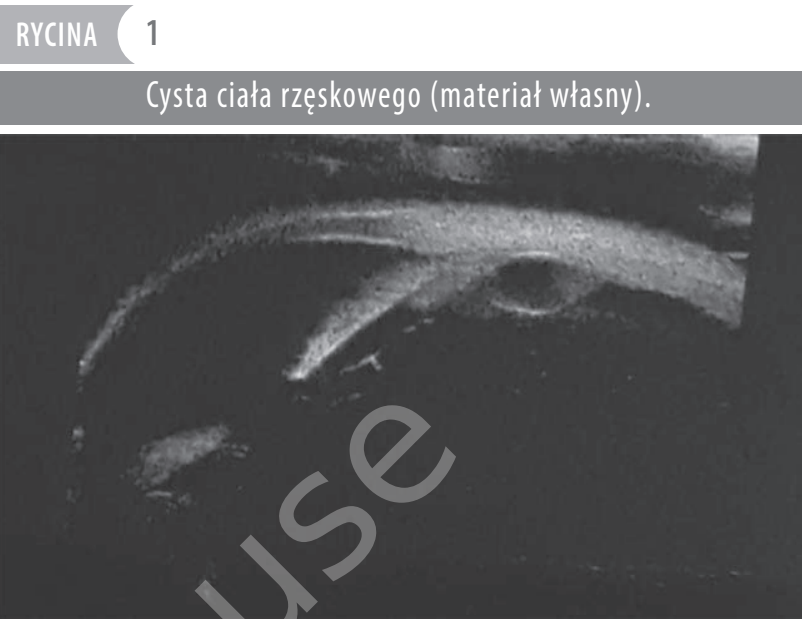

\section{Jaskra wrodzona}

W jaskrze wrodzonej obrazowanie metodą UBM przeprowadzamy zwykle w znieczuleniu ogólnym. Wynika to z głównie z wieku pacjenta, którym najczęściej jest małe dziecko. Warto przed wykonaniem goniotomii bądź trabekulektomii wykluczyć obecność odwarstwienia siatkówki, a także guzów wewnątrzgałkowych. W tym celu posługujemy się sondą typu B, ponieważ nie możemy przeprowadzić badania w mikroskopie ze względu na obecność przymglonej rogówki, która znacznie utrudnia badanie.

Niekontrolowane CWG u noworodków prowadzi nie tylko do zwiększania zagłębienia w tarczy nerwu wzrokowego, ale też do powiększania się całej gałki ocznej. W tych przypadkach nie można zapominać o badaniu biometrycznym [10]. Wykonując badanie UBM, obserwujemy: głęboką komorę przednią, szeroki kąt przesączania, tkankę mezodermalną w kącie przesączania, przedni przyczep tęczówki, ścieńczałą tęczówkę, wydłużone wyrostki rzęskowe oraz rozciągnięcie ciała rzęskowego i obwódki rzęskowej [1].

\section{PLANOWANIE ZABIEGÓW CHIRURGICZNYCH I OCENA ICH SKUTECZNOŚCI}

Trabekulektomia to złoty standard chirurgicznego leczenia jaskry. Jest to operacja przetokowa, która ma na celu wytworzenie nowej drogi odpływu cieczy wodnistej z komory przedniej pod torebkę Tenona i do przestrzeni podspojówkowej.

UBM daje możliwość oceny zarówno operacji przetokowych, jak i innych zabiegów przeciwjaskrowych. Możemy sprawdzić drożność sklerostomii, poprawność wykonania obwodowo irydektomii oraz cechę pęcherzyka filtrującego czy jest płaski, płytki bądź głęboki [5].

Podział pęcherzyka filtracyjnego na podstawie badania UBM opisujemy ze względu na poniższe cechy: hiperrefleksyjność, widoczność drogi odpływu pod płatkiem twardówki, wytworzenie niewielkich jam wypełnionych 
płynem i wysokość pęcherzyka. Zgodnie z powyższym pęcherzyki dzielimy na:

- z niską refleksyjnością (low reflective - typ L)

- $\mathrm{z}$ wysoką refleksyjnością (high reflective - typ $\mathrm{H}$ )

- otorbione (encapsulated - typ E)

- płaskie (flat - typ F) [5].

Oczy z dobrym CWG po operacjach kwalifikowane są głównie jako typ L - mają niską bądź umiarkowaną refleksyjność, widoczna jest droga odpływu w twardówce, a pęcherzyk jest wysoki. Pęcherzyki płaskie i otorbione świadczą o nieudanym zabiegu.

Skuteczność metody UBM wraz pomiarem CWG oraz ich użyteczność w ocenie filtracji w pęcherzyku filtrującym dowiódł w swoich badaniach Avitabile [17]. Dokonał on analizy 103 pęcherzyków filtracyjnych pod kątem wewnętrznej refleksyjności oraz obecności drogi odpływu cieczy wodnistej pod płatkiem twardówki. Następnie sklasyfikował na trzy kategorie (dobry, umiarkowany, słaby), które wskazywały na poprawność funkcji pęcherzyka i wiązały się z CWG.

W UBM możemy również oceniać inne operacje przeciwjaskrowe, takie jak: wszczepienie implantu GSM+, implantu Ex-Press, zastawki Ahmeda, a także ocenić stan po fakokanaloplastyce czy sklerektomii.

\section{PORÓWNANIE UBM Z AS-OCT}

UBM jest niezastąpionym i bezkonkurencyjnym urządzeniem do badania patologii ciała rzęskowego, ma też ogromne znaczenie w diagnozowaniu przyczyn jaskry wtórnej. Metoda UBM zapewnia badającemu dużą rozdzielczość i dużą powtarzalność. Nie jest to jednak badanie tak szybkie jak AS-OCT (Anterior Segment OCT). Wymaga znieczulenia miejscowego oraz współpracy pacjenta, dlatego przeprowadzenie badania UBM $\mathrm{u}$ dzieci bywa niekiedy nie lada wyzwaniem. Dużym minusem dla lekarza jest trudność w opanowaniu techniki tego badania.

W badaniu AS-OCT istotnym plusem jest to, że jest bezkontaktowe oraz łatwe do nauczenia. Duży minus stanowi brak możliwości obrazowania ciała rzęskowego.

Skuteczność obu technik poddawana była wielu próbom. Między innymi Wu wykazał, że większą czułość i swoistość w ocenie pęcherzyków filtracyjnych po trabekulektomii wykazuje AS-OCT [18]. Natomiast Mansouri udowodnił, że AS-OCT nie może zastąpić badania UBM w ocenie kąta przesączania [19].

\section{PODSUMOWANIE}

Ultrabiomikroskopia jest znakomitym narzędziem do oceny struktur przedniego odcinka. Przede wszystkim pozwala uwidocznić komorę tylną, której przy zwykłym badaniu klinicznym okulista nie może obserwować. Jest to pierwszorzędne narzędzie do zrozumienia patofizjologii wielu rodzajów jaskry. Pozwala też obiektywnie zobrazować struktury przedniego odcinka i zachować je w dokumentacji. Operatorom służy zarówno przed zabiegami chirurgicznymi, jak po nim właściwe wykorzystanie UBM może ułatwić pracę i dać sporo informacji o pacjencie.

Źródto rycin: Wszystkie ryciny pochodzą z materiatów własnych autora/autorów.

\author{
ADRES DO KORESPONDENCJI \\ lek. Grzegorz Jasina \\ Szpital Specjalistyczny im. Stefana Żeromskiego w Krakowie, \\ Oddział Okulistyczny z Pododdziałem \\ 31-913 Kraków, 0s. Na Skarpie 66 \\ e-mail: gmjasina@gmail.com
}

\author{
ORCID \\ Grzegorz Jasina - ID - http://orcid.org/0000-0002-5481-8436 \\ Marta Misiuk-Hojło - ID - http://orcid.org/0000-0002-4020-3203
}

\section{Piśmiennictwo}

1. Stodolska-Nowak A, Adamski W, Brązert A. Zastosowanie ultrabiomikroskopii w diagnostyce i monitorowaniu pacjentów z jaskrą. Okul Dypl. 2019; 2: 9-16.

2. Dietlein T, Engels B, Jacobi P et al. UBM-guided chamber angle surgery for glaucoma management: an experimental study. Eye. 2003; 17: 340-5.

3. Higgitt AC. The dark-room test. Br J of Ophthalmol. 1954; 38: 242-7.

4. Wang N, Lai M, Cheng X et al. Ultrasound biomicroscopic dark room provocative test. Zhonghua Yan Ke Za Zhi. 1998; 34(3): 183-6, 12.

5. Dada T, Kumar G, Kumar Mishra S. Ultrasound Biomicroscopy in Glaucoma: An Update. J Curr Glaucoma Pract. 2008; 2(3): 17-32.

6. Dada T, Gupta V, Deepak KK et al. Narrowing of the anterior chamber angle during Valsalva maneuver: A possible mechanism for angle closure. Eur J Ophthalmol. 2006; 16: 81-91.

7. Kosmala J, Grabska-Liberek I. Ultrabiomikroskopia - zastosowanie w okulistyce. Termedia, Poznań 2014. 
8. Méndez-Hernández C, Garcia-Feijoo J, Cuina-Sardina R. Ultrasound biomicroscopy in pigmentary glaucoma. Arch Soc Esp Oftalmol. 2003; 78(3): 137-42.

9. Pillunat L, Bohm A, Fuisting B. Ultrasound biomicroscopyin pigmentary glaucoma. Ophthalmologe. 2000; 97: 268-71.

10. Rockwood E, Sharma S, Hayden B et al. Glaucoma. In: Singh A, Hayden B, Pavlin C (ed). Ultrasound Clinics. Elsevier Inc, USA, Canada 2008: 207-15.

11. Wei W, Yang W, Chen Z et al. A study on ocular anterior segment structure after scleral buckling surgery for retinal detachment. Zhonghua Yan Ke Za Zhi. 1999; 35(4): 309-11, 317.

12. Fleck B, How large must an iridotomy be? Br J Ophthalmol. 1990; 74: 583-8.

13. Dada T, Mohan S, Sihota R et al. Comparison of ultrasound biomicroscopic parameters after laser iridotomy in eyes with primary angle closure and primary angle closure glaucoma. Eye. 2007; 21: 956-61.

14. Kumar G. Prevalence of plateau iris in primary angle closure suspects, a UBM study. Ophthalmology. 2008; 115: 430-4.

15. Garudadri C, Chelerkar V, Nutheti R. An ultrasound biomicroscopic study of the anterior segment in Indian eyes with primary angle-closure glaucoma. J Glaucoma. 2002; 1: 502-7.

16. Marigo F, Finger P. Anterior segment tumors: current concepts and innovations. Surv Ophthalmol. 2003; 48: 569-93.

17. Avitabile T, Russo V, Uva M et al. Ultrasound-biomicroscopic evaluation of filteringblebs after laser suture lysis trabeculectomy. Ophthalmologica. 1998; 212: 117-21.

18. Wu Q, Zhang Y, Song B et al Evaluation of the bleb morphology and the function of postfiltration surgery using slit-lamp adapted optical coherence tomography and ultrasound biomicroscopy in glaucoma patients. Zhonghua Yan Ke Za Zhi. 2008; 44: 402-7.

19. Mansouri K, Sommerhalder J, Shaarawy T. Prospective comparison of ultrasound biomicroscopy and anterior segment optical coherence tomography for evaluation of anterior chamber dimensions in European eyes with primary angle closure. Eye. 2010; 24(2): 233-9.

Wkład autorów:

Grzegorz Jasina: przygotowanie manuskryptu; Marta Misiuk-Hojło: ostateczna ocena manuskryptu.

Konflikt interesów:

Nie występuje.

Finansowanie:

Nie występuje.

Etyka:

Treści przedstawione w artykule są zgodne z zasadami Deklaracji Helsińskiej, dyrektywami EU oraz ujednoliconymi wymaganiami dla czasopism biomedycznych.
Authors' contributions:

Grzegorz Jasina: writing of manuscript; Marta Misiuk-Hojło: final review of manuscript. Conflict of interest:

None.

Financial support:

None.

Ethics:

The content presented in the article complies with the principles of the Helsinki Declaration, EU directives and harmonized requirements for biomedical journals. 